\author{
PETR HORYL*, RICHARD ŠŇUPÁREK**, PAVEL MARŠÁLEK*, \\ KRZYSZTOF PACZEŚNIOWSKI***
}

\title{
SIMULATION OF LABORATORY TESTS OF STEEL ARCH SUPPORT
}

\author{
SYMULACJA LABORATORYJNYCH BADAŃ STALOWEJ OBUDOWY LUKOWEJ
}

\begin{abstract}
The total load-bearing capacity of steel arch yielding roadways supports is among their most important characteristics. These values can be obtained in two ways: experimental measurements in a specialized laboratory or computer modelling by FEM. Experimental measurements are significantly more expensive and more time-consuming. However, for proper tuning, a computer model is very valuable and can provide the necessary verification by experiment. In the cooperating workplaces of GIG Katowice, VSB-Technical University of Ostrava and the Institute of Geonics ASCR this verification was successful. The present article discusses the conditions and results of this verification for static problems. The output is a tuned computer model, which may be used for other calculations to obtain the load-bearing capacity of other types of steel arch supports. Changes in other parameters such as the material properties of steel, size torques, friction coefficient values etc. can be determined relatively quickly by changing the properties of the investigated steel arch supports.
\end{abstract}

Keywords: total load-bearing capacity, steel arch yielding support, rigid support, FEM

Najważniejszymi parametrami wytrzymałościowymi stalowych, podatnych odrzwi obudowy wyrobisk korytarzowych jest ich maksymalna i robocza nośność. Wartości tych nośności mogą być określane dwoma sposobami: doświadczalnie, w specjalistycznym laboratorium badawczym lub za pomocą modelowania komputerowego metodą elementów skończonych (MES). Badania laboratoryjne odrzwi są drogie i czasochłonne, jednak dla kalibracji i weryfikacji modelu numerycznego wyniki tych badań są niezbędne. Weryfikację tą, zakończoną sukcesem, przeprowadzono we współpracy Głównego Instytutu Górnictwa w Katowicach, Technicznego Uniwersytetu VSB w Ostrawie oraz Instytutu Geoniki ASCR w Ostrawie. Niniejszy artykuł przedstawia przebieg procesu kalibracji modelu numerycznego odrzwi w warunkach obciążeń statycznych. W efekcie tych działań uzyskano model komputerowy odrzwi odwzorowujący ich

* VSB-TECHNICAL UNIVERSITY OF OSTRAVA, DEPARTMENT OF APPLIED MECHANICS, 17. LISTOPADU 15, 70833 OSTRAVA, CZECH REPUBLIC, CENTRE OF EXCELLENCE IT4INNOVATIONS

** INSTITUTE OF GEONICS ASCR, STUDENTSKÁ 1768, 70800 OSTRAVA, CZECH REPUBLIC, INSTITUTE OF CLEAN TECHNOLOGIES FOR MINING AND UTILIZATION OF RAW MATERIALS FOR ENERGY USE

*** CENTRAL MINING INSTITUTE, DEPARTMENT OF MECHANICAL DEVICES TESTING, PLAC GWARKÓW 1, 40-166 KATOWICE, POLAND 
pracę w stanowisku badawczym. Opracowany model może być wykorzystywany do obliczania nośności innych typów odrzwi. Zmiany parametrów odrzwi wpływających na ich nośność, takich jak własności mechaniczne stali, wielkość momentu dokręcenia nakrętek śrub strzemion, współczynnik tarcia itp. mogą być zmieniane w modelu stosunkowo szybko.

Słowa kluczowe: nośność odrzwi, stalowa obudowa podatna łukowa, obudowa sztywna, metoda elementów skończonych

\section{Introduction}

A steel arch yielding support of roadways is a widely used support structure in all European coal mining. Knowledge of its properties and behaviour under different loading patterns is necessary for the design of suitable support constructions for various mining conditions. Static calculations of arch supports (mostly statically undetermined two-joint constructions) are complicated and require certain simplifications, regarding their loading and deformation.

Laboratory testing of steel arch supports on big hydraulic frames (which have recently become available in the Central Mining Institute Katowice and DMT Essen) gives real data on the behaviour and load-bearing capacity of support constructions. However, that such tests are very expensive and time-consuming. Methods of computer modelling, with efficient programs, are becoming recognised as suitable for comparison of different constructions of roadway supports under various loadings. Modelling of a whole yielding support construction is exacting and also demands verification based on testing results. The authors from the VŠB Technical University Ostrava, Central Mining Institute Katowice and Institute of Geonics ASCR Ostrava here present results from both testing and computer modelling of the standard four-segment steel arch roadways support.

\section{Laboratory testing}

An experimental investigation was realized in the Laboratory of Mechanical Devices Testing at GIG Katowice. The testing equipment makes it possible to simulate and measure the static loading of arch supports due to the pressure of surrounding rocks. The external loading is provoked by hydraulic actuator. Each element consists of a hydraulic cylinder with regulated acting force from 0 to $0.7 \mathrm{MN}$ and a joint segment with length $0.24 \mathrm{~m} / 0.5 \mathrm{~m} / 0.63 \mathrm{~m} / 1 \mathrm{~m}$. Each element is independently controlled, which makes it possible to use practically any scheme of loading (Fig. 1).

The laboratory can use a maximum of 14 force elements on the perimeter of the support with a total force of 7.5 MN. A monitoring system contains a 60-channel amplifier HBM 60 (firm Hottinger). The system enables recording of measurements by different sensing units such as tensometric indicators of pressure and force or resistance indicators of movement and slip. The scanned data are sent to a computer unit and recorded. The self-designed computer programme Chameleon makes it possible to transform the measured data into final graphic and text results.

Tests of steel arch supports are performed in two variations: as a rigid construction (unyielding segments are fixed by welding of double parts) and as a yielding support with standard friction joints. The scheme of both tests is shown in Fig. 1. 


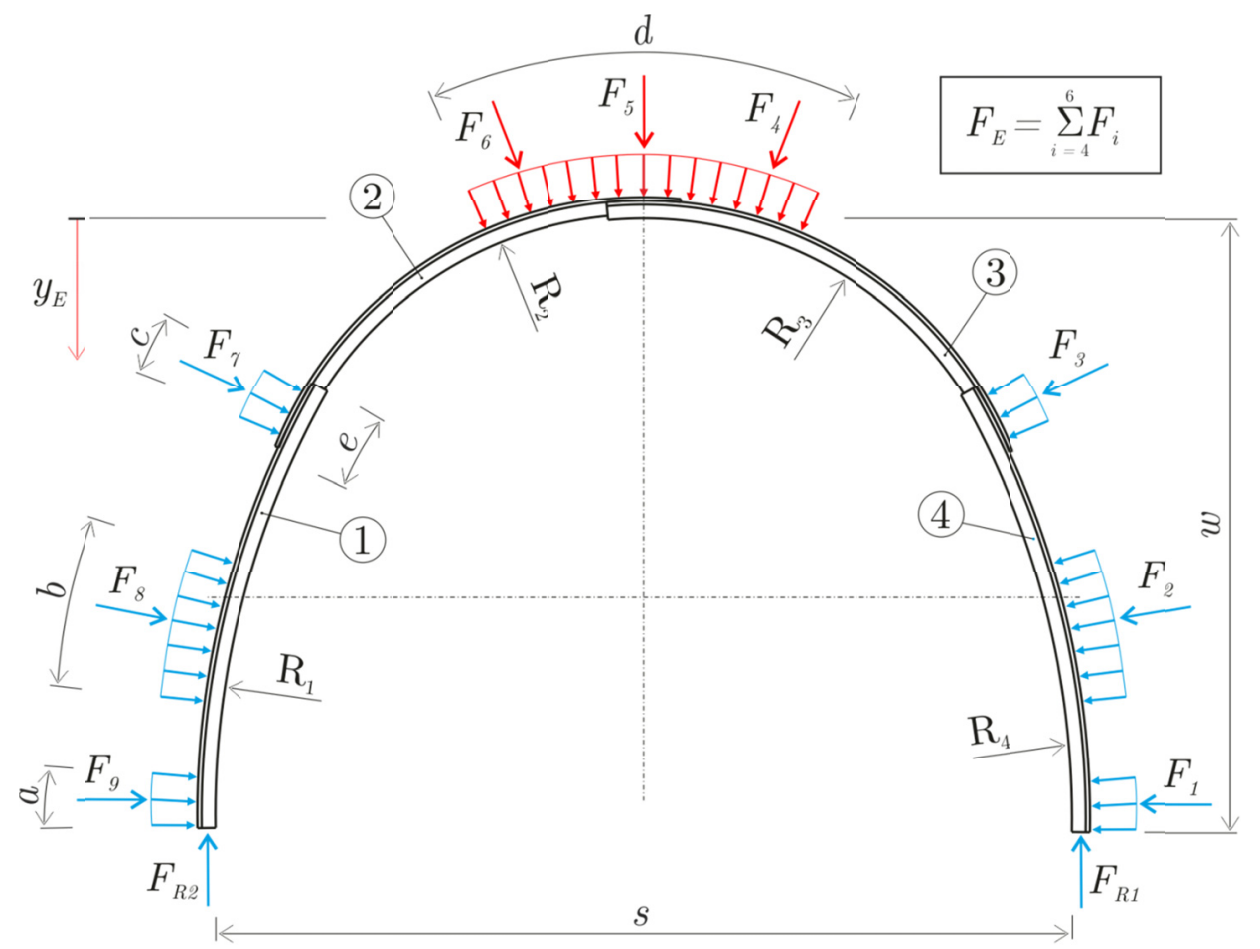

Fig. 1. Scheme of test, front view

The monitoring of the test considers parameters as follows:

- Vertical deformation $y_{E}$,

- Forces of active elements $F_{4}, F_{5}, F_{6}$,

- Forces of passive elements $F_{1}, F_{2}, F_{3}, F_{7}, F_{8}, F_{9}$,

- Reactions under legs $F_{R 1}, F_{R 2}$,

- Slips in single connections (in the case of the yielding construction).

Recording of the parameters is provided at intervals of $10 \mathrm{~s}$ with velocity of loading $0.6 \mathrm{kN} / \mathrm{s}$. The testing of the supports complies with the requirements of the standard (Pacześniowski $\&$ Taborek, 2014a). Loading of yielding supports continues until reaching a vertical deformation of $20 \%$ of the original height, or until damage or large plastic deformation occurs.

The subjects of the laboratory testing are common arch supports SP 16 used in Ostrava Karvina mines with basic dimensions width $s=5920 \mathrm{~mm}$ and height $w=4240 \mathrm{~mm}$. The frame consists of four segments of the profile TH 29 (steel $31 \mathrm{Mn} 4 \mathrm{~V}$ ) connected by clamps (friction bolt connections). The overlap length of segments is $e=500 \mathrm{~mm}$ with three clamps. The tightening torque of bolts is $T=400 \mathrm{Nm}$ or $T=450 \mathrm{Nm}$. All geometrical properties are shown in Tab. 1 .

Three tests with the same scheme of loading (Fig. 1) are conducted:

- Rigid (unyielding) construction,

- Yielding construction with tightening torque of bolts $T=400 \mathrm{Nm}$,

- Yielding construction with tightening torque of bolts $T=450 \mathrm{Nm}$. 
Geometry of support

\begin{tabular}{|c|c|c|c|}
\hline \hline Parameter & {$[\mathbf{m m}]$} & Parameter & {$[\mathbf{m m}]$} \\
\hline$s$ & 5920 & $a$ & 170 \\
\hline$w$ & 4240 & $b$ & 1000 \\
\hline$e$ & 500 & $c$ & 220 \\
\hline$R_{1}=R_{4}$ & 5950 & $d$ & 3000 \\
\hline$R_{2}=R_{3}$ & 2620 & & \\
\hline
\end{tabular}

The results of the three tests in relation to acting forces versus vertical deformation are displayed in Figs. 2-4 (Pacześniowski \& Taborek, 2014b).

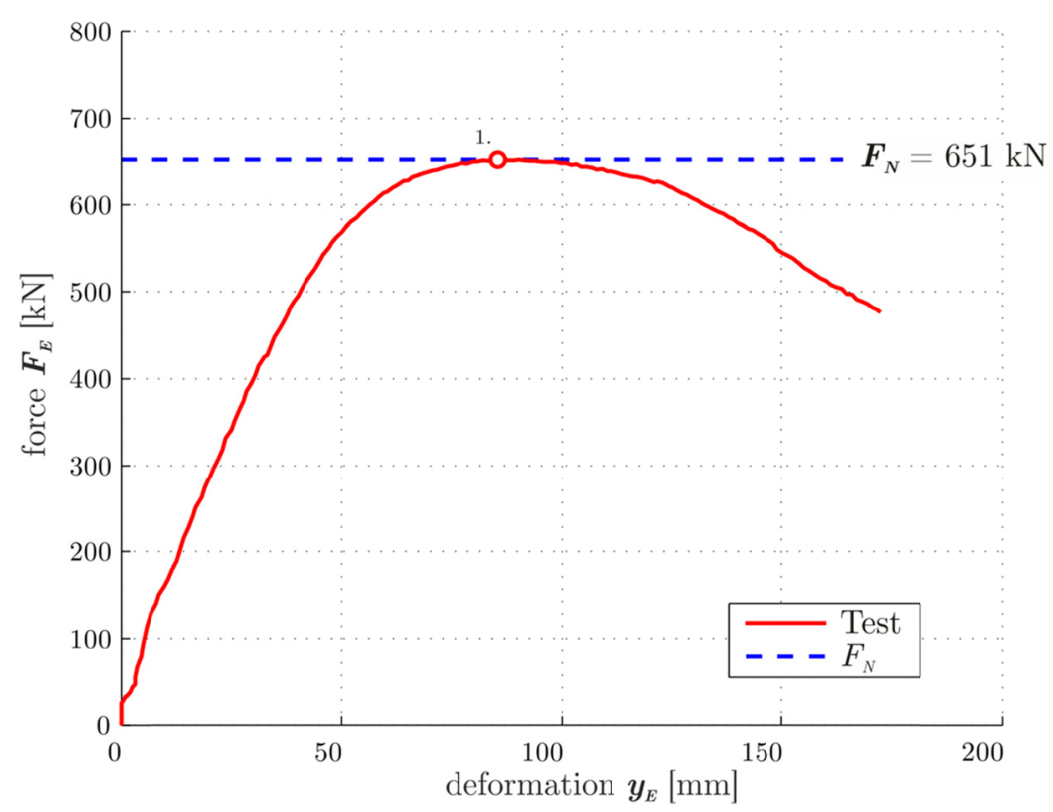

Fig. 2. Course of loading $F_{E}[\mathrm{kN}]$ and vertical deformation $y_{E}[\mathrm{~mm}]$ of rigid support

\section{Computer modelling}

Computer modelling of the load-bearing capacity of the steel arch support (Fig. 1) was performed using the massively scalable strongly nonlinear solver MARC. The finite element models of the arch supports and clamps were created and assembled according to drawings without shape simplification. The screws were modelled in a specific manner. The beam elements used were attached by multi-point constraints elements (MPC) to the yokes. The stiffness of the hydraulic cylinders was represented by spring elements. The supporting mechanisms of the hydraulic cylinders were created using MPC elements connecting one layer of the elements with the joint mechanism. The FE model is shown in Fig. 5. 


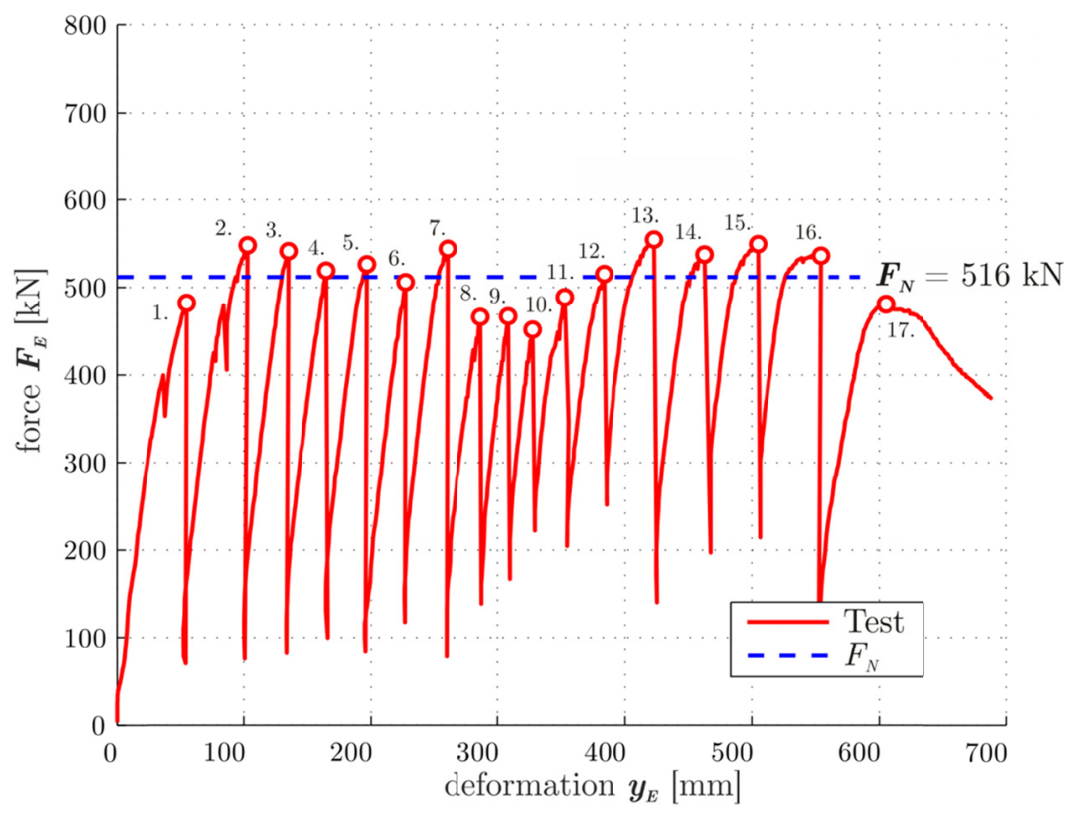

Fig. 3. Course of loading $F_{E}[\mathrm{kN}]$ and vertical deformation $y_{E}[\mathrm{~mm}]$ of yielding support $(T=400 \mathrm{Nm})$

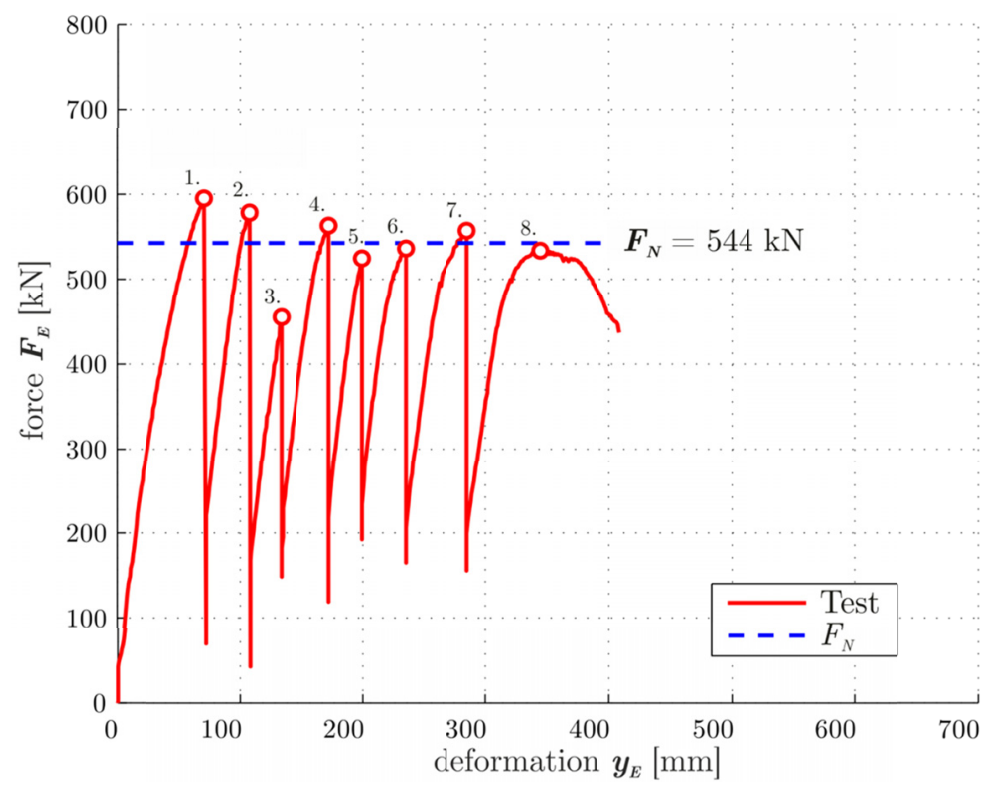

Fig. 4. Course of loading $F_{E}[\mathrm{kN}]$ and vertical deformation $y_{E}[\mathrm{~mm}]$ of yielding support $(T=450 \mathrm{Nm})$ 


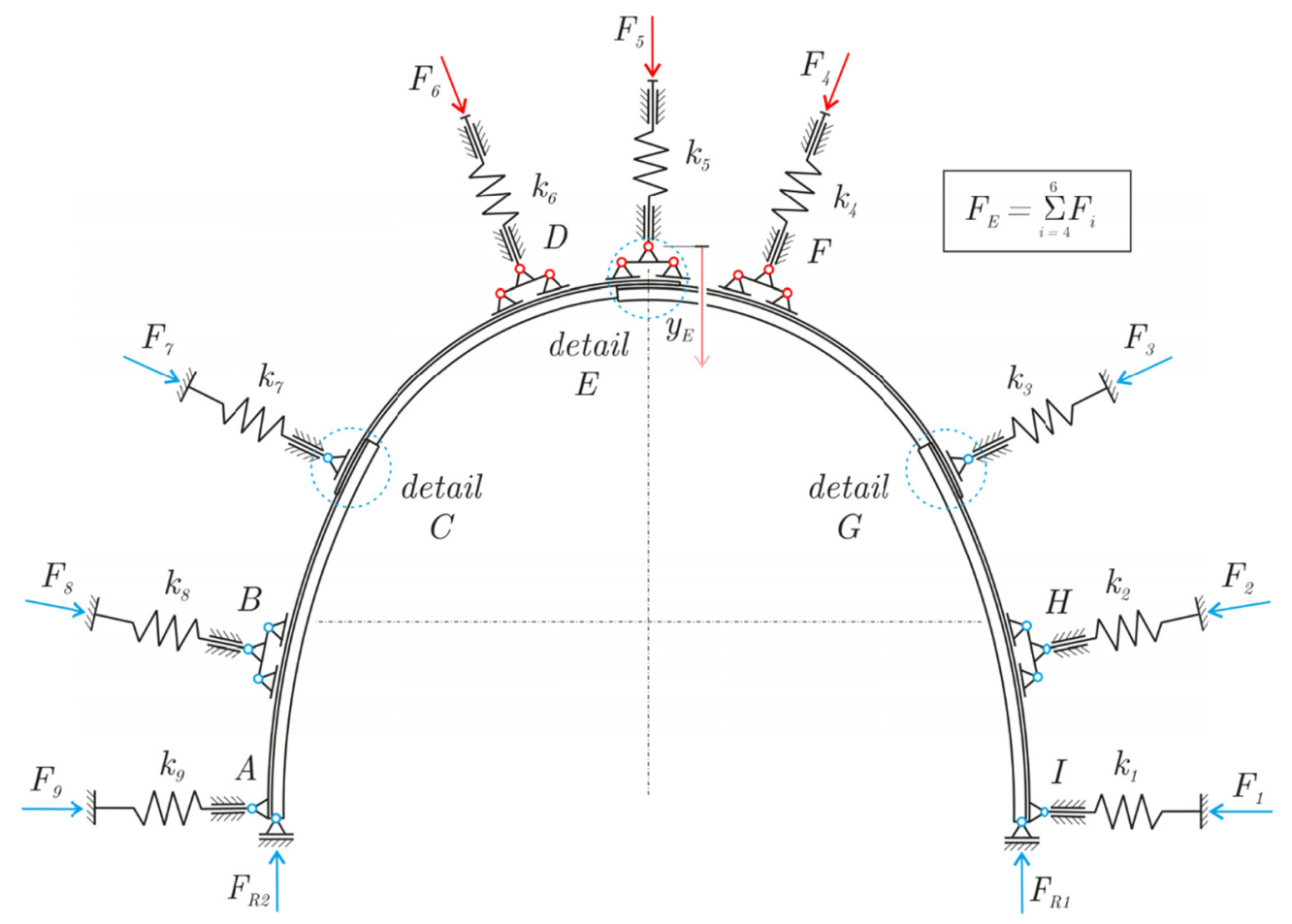

Fig. 5. Boundary conditions, front view

The FE model parameters are presented in Table 2.

TABLE 2

Finite elements used for creation of rigid support

\begin{tabular}{|c|c|c|}
\hline \hline Type of elements & MARC Finite Elements & Number of elements \\
\hline Solid elements & $\begin{array}{c}\text { Hex8 (SOLID7) } \\
\text { Penta6 (SOLID136) }\end{array}$ & 260000 \\
\hline Spring elements & - & 9 \\
\hline Pre-tensioned bolts & Overclosure tying (69) & 9 \\
\hline Screw body $d=22.05 \mathrm{~mm}$ & Line2 (Beam98) & 18 \\
\hline Multi-point constraints & RBE2 & 39 \\
\hline
\end{tabular}

For the mathematical description of the behaviour of the material properties of all the components, a multi-linear model (bilinear plus ideal plastic material from ultimate stress) was used for the data described in Table 3.

The yielding stress and ultimate stress of the steel support material $(31 \mathrm{Mn} 4 \mathrm{~V})$ were verified by lab experiments (Poruba \& Horyl, 2014).

Among all the bodies in contact, the frictional contacts were defined with a Coloumbarctangent friction model. The step function approximation is based on smooth transitions of 
Material properties of steel parts

\begin{tabular}{|c|c|c|c|c|}
\hline \multirow[b]{2}{*}{ Structure part } & \multicolumn{4}{|c|}{ Material properties } \\
\hline & $\begin{array}{c}\text { Young's modulus } \\
\text { of elasticity } \\
E \text { [MPa] }\end{array}$ & $\begin{array}{c}\text { Yielding stress } \\
s_{y}[\mathrm{MPa}]\end{array}$ & $\begin{array}{c}\text { Ultimate stress } \\
\quad s_{u}[\mathrm{MPa}]\end{array}$ & $\begin{array}{c}\text { Elongation } \\
\quad A[\%]\end{array}$ \\
\hline Steel support 31Mn4V & \multirow{4}{*}{200000} & 520 & 650 & 19 \\
\hline Weld & & 364 & 455 & 19 \\
\hline Upper / lower yoke (E295) & & 295 & 470 & 20 \\
\hline High strength screw M24 (8.8) & & 640 & 800 & 12 \\
\hline Stiffness of hydraulic cylinders & & \multicolumn{3}{|c|}{$k_{1}-k_{9}=9 \mathrm{kN} / \mathrm{mm}$} \\
\hline
\end{tabular}

Contact settings and properties of pre-tensioned bolts

\begin{tabular}{|c|c|c|c|}
\hline \hline Structure part & $\begin{array}{c}\text { Coefficient of friction } \\
\boldsymbol{f}[-\boldsymbol{I}\end{array}$ & $\begin{array}{c}\text { Torque } \\
\boldsymbol{T}[\mathbf{N m}]\end{array}$ & $\begin{array}{c}\text { Axial force } \\
\boldsymbol{F}_{\boldsymbol{O}}[\mathbf{k N}]\end{array}$ \\
\hline Threads of bolts & 0.13 & 400 & 84.407 \\
\hline Under nuts & 0.17 & 450 & 94.957 \\
\hline Between segments \& yokes & 0.27 & & \\
\hline
\end{tabular}

relative speed between the contact pairs. The values of the coefficients of friction and tightening torque of bolts conversion for axial force are shown in Table 4 .

Calculations were carried out in two loading steps. The first step realized tightening torque of the screws. In the second step the structures were loaded by the hydraulic cylinders (the forces $F_{4}=F_{5}=F_{6}$ ). The gradual linear increase in loading forces leads to deformation of the steel arch support. Dependence of the force $F_{E}\left(F_{E}=F_{4}+F_{5}+F_{6}\right)$ on vertical deformation of the excavation supports $y_{E}$ was observed, as shown in Fig. 5 .

\subsection{Rigid support}

To check the material model and the respective constants obtained from the literature ("Steel Qualities", 2015) we used the test results from the experimental lab (Pacześniowski \& Taborek, 2014b). Each overlap joint was screwed together by two clamps on the ends. At the interface of the clamped profile, fillet welds were made so as to prevent slipping. The finite element model of the rigid support was created by mesh dragging from plane profile TH29. Discretization of the clamps was also created by dragging. This gave rise to a mapped mesh that is suitable for large plastic deformations. Each element forming the weld joint was made manually. The FE model detail is shown in Fig. 6 .

The dependence of the vertical deflection $y_{E}$ on the total applied force $F_{E}$ was again examined. Fig. 7 shows a comparison of the results obtained by computer modelling with the data from the laboratory measurements. From this it is clear that there is excellent agreement with the experiment. The results of the calculation credibly describe the behaviour of the steel arch support under both elastic and plastic strain. 


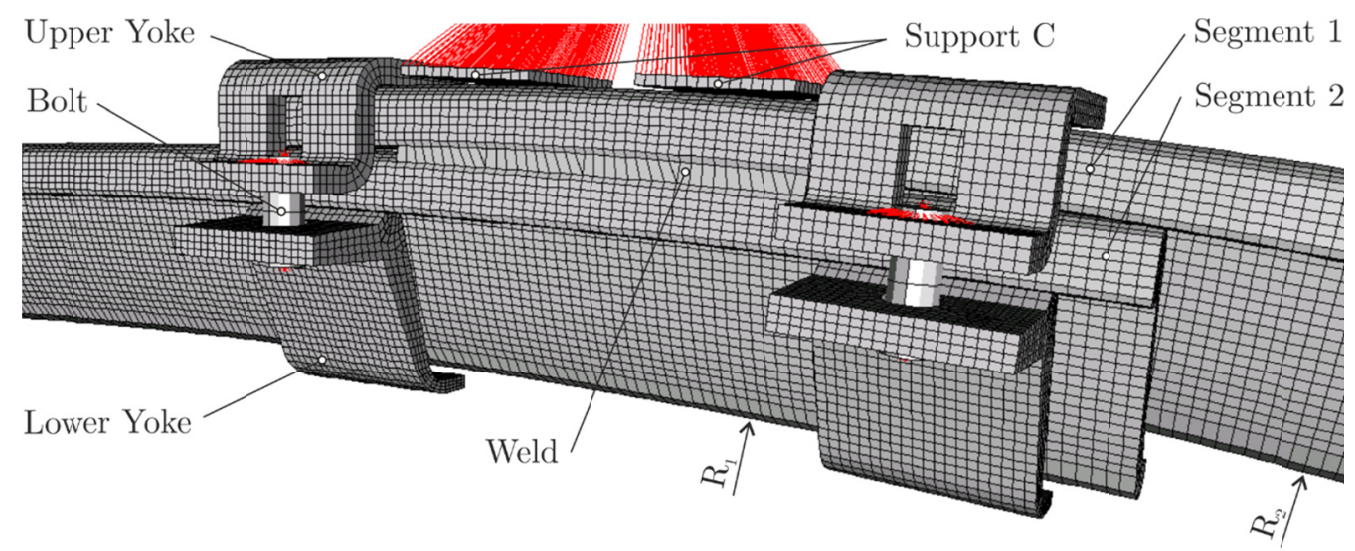

Fig. 6. FEM model of rigid support- detail C

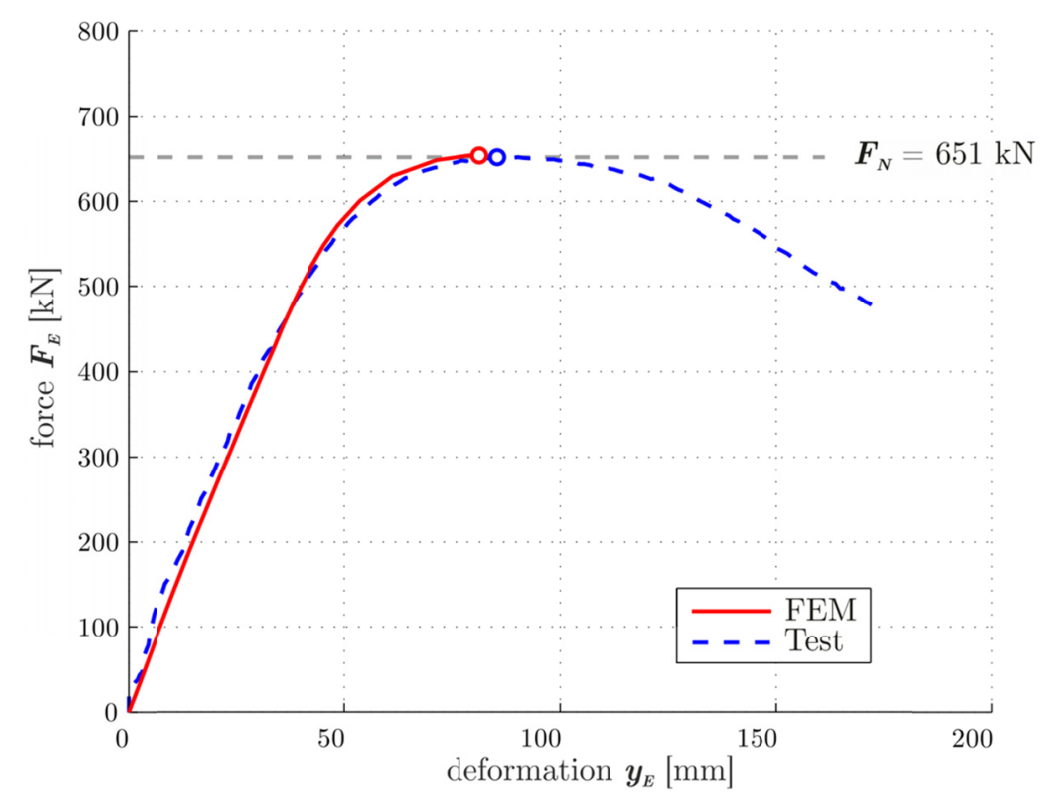

Fig. 7. Comparison of testing of rigid support and FEM simulation

Limits from testing of rigid support and FEM simulation

\begin{tabular}{|c|c|c|}
\hline \hline \multirow{2}{*}{ Subject } & \multicolumn{2}{|c|}{ Properties } \\
\cline { 2 - 3 } & $\begin{array}{c}\text { Deformation } \\
y_{E}[\mathbf{m m}]\end{array}$ & $\begin{array}{c}\text { Total load-bearing capacity } \\
\boldsymbol{F}_{E}[\mathrm{kN}]\end{array}$ \\
\hline Measurement & $\mathbf{8 5}$ & $\mathbf{6 5 1}$ \\
\hline FEM simulation & $\mathbf{8 2}$ & $\mathbf{6 5 4}$ \\
\hline
\end{tabular}


The field of total deformation before collapse is presented in Fig. 8. It is possible to notice a significant asymmetry in the upper part of the steel arch support. This phenomenon arises and creates a plastic hinge (labelled: Plastic joint 1 in Fig. 9) which causes the interruption of the calculation because of the huge plastic deformation. The mathematical model diverges when the limit values of displacements are reached.

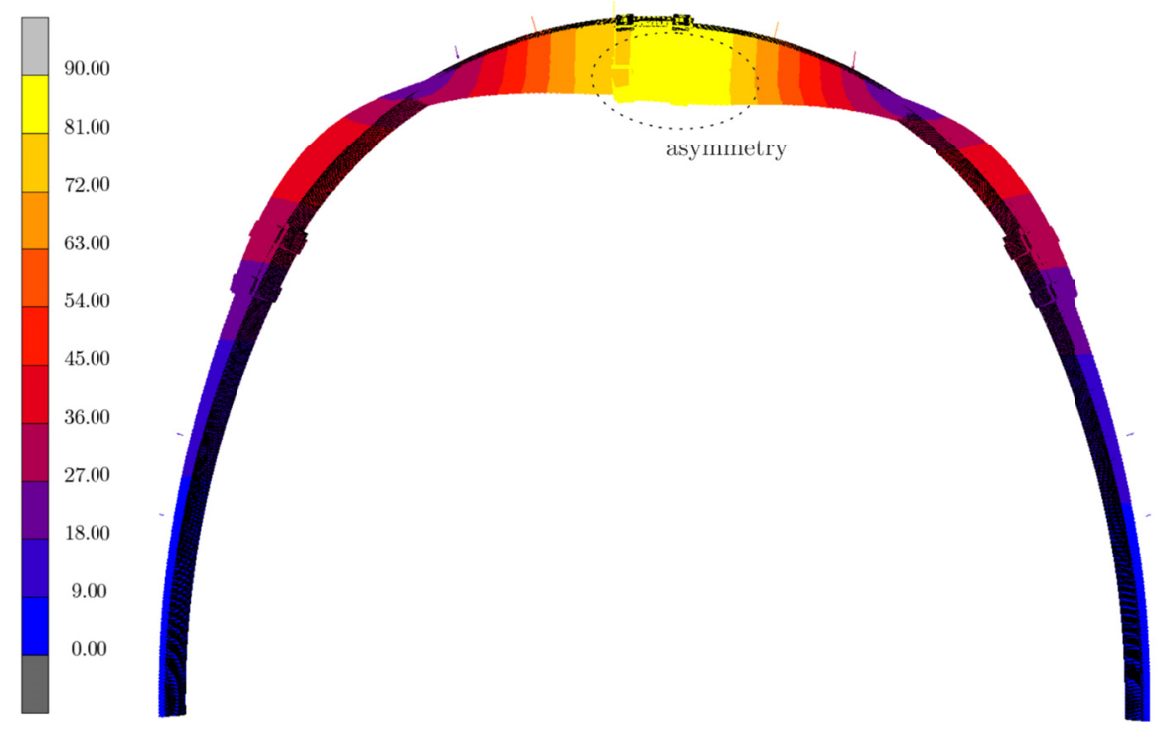

Fig. 8. Field of total deformation $x \quad[\mathrm{~mm}]$ on rigid support before collapse - load $F_{E}=654 \mathrm{kN}$

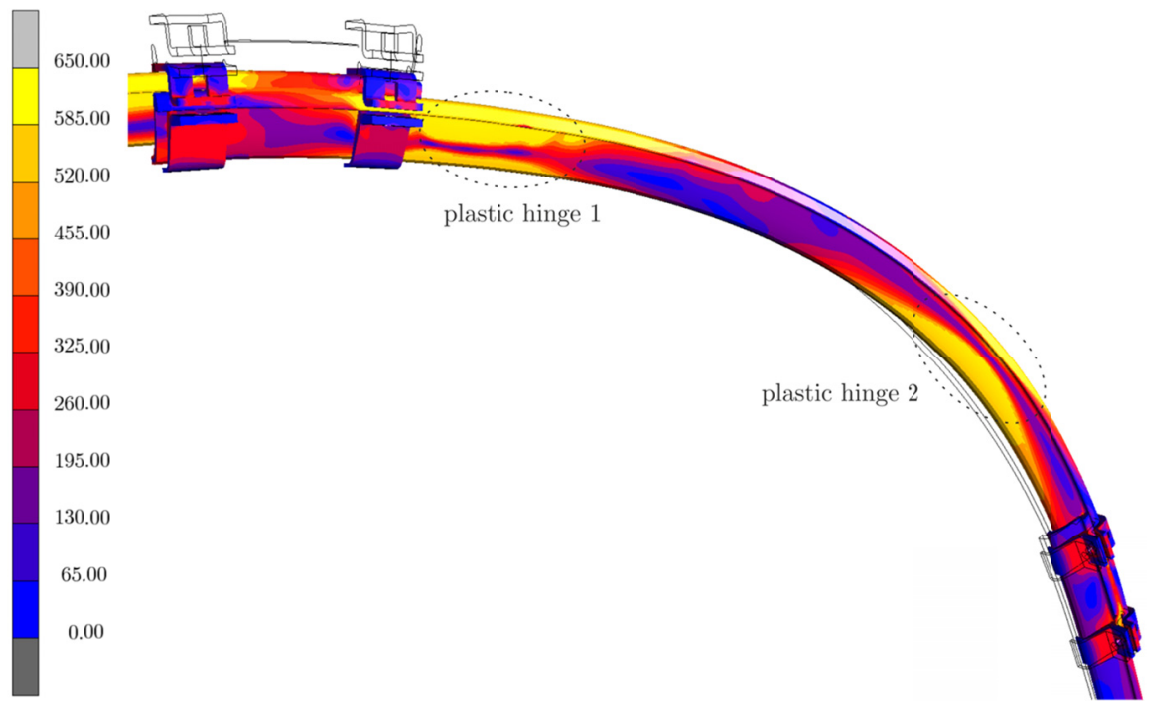

Fig. 9. Field of equivalent stress - von Mises $\sigma[\mathrm{MPa}]$ on rigid support before collapse - load $F_{E}=654 \mathrm{kN}$ 


\subsection{Yielding support}

The FE model of the yielding support (Fig. 10) was formed in a similar way to the model of the rigid support (Horyl \& Šňupárek \& Hlaváčková, 2013). The model was not welded and three pairs of yokes were used for the implementation of each clamping joint.

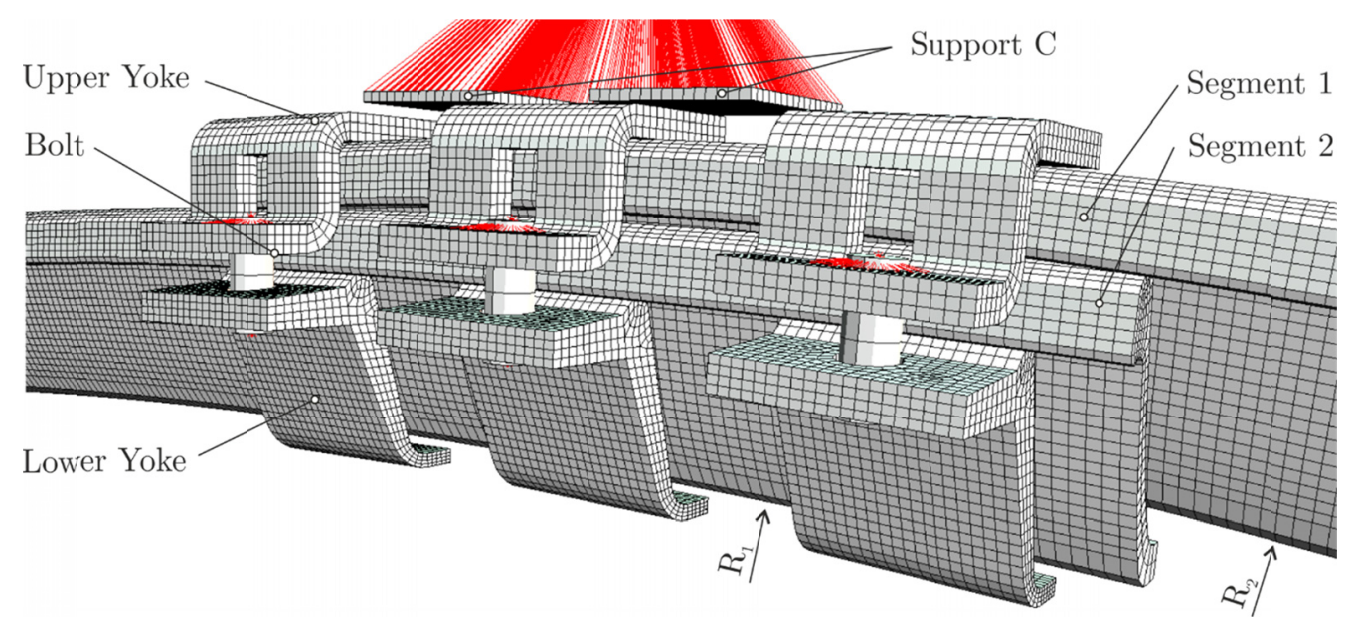

Fig. 10. FEM model of yielding support - detail C

The aim of this analysis was to determine the total load-bearing capacity of the steel arch support $F_{N}$ at two different values of tightening torque of the screws. From the results of the laboratory tests, it can be judged (Fig. 3 and 4) that gradual increase of the loading force $F_{E}$ with different tightening torque moments leads to plastic deformation of the steel arch support. Here we again investigated the dependence of the vertical deflection $y_{E}$ on the applied force $F_{E}$ due to the hydraulic cylinders. This dependence is plotted and compared with experimental data in Fig. 11. The maximum load-bearing capacity is achieved when there is a divergence due to rigid body motion. The frictional forces induced by the tension in the screws are at this moment overcome ("the force breaking the frictional joint", Brodny, 2012) and the structure becomes a mechanism.

A comparison of the limit values is given in Tab. 6

TABLE 6

Comparison of limits from testing of yielding supports and FEM simulations

\begin{tabular}{|c|c|c|c|}
\hline \hline Subject & $\begin{array}{c}\text { Deformation at the first } \\
\text { slip } \boldsymbol{y}_{\mathbf{1}}[\mathbf{m m}]\end{array}$ & $\begin{array}{c}\text { Loading at the first slip } \\
\boldsymbol{F}_{\mathbf{1}}[\mathbf{k N}]\end{array}$ & $\begin{array}{c}\text { Total load-bearing } \\
\text { capacity } \boldsymbol{F}_{\boldsymbol{N}}[\mathbf{k N}]\end{array}$ \\
\hline Test $T=400 \mathrm{Nm}$ & $\mathbf{5 5}$ & 482 & $\mathbf{5 1 6}$ \\
\hline FEM $T=400 \mathrm{Nm}$ & $\mathbf{5 6}$ & $\mathbf{5 0 1}$ & - \\
\hline Test $T=450 \mathrm{Nm}$ & $\mathbf{7 0}$ & 595 & $\mathbf{5 4 4}$ \\
\hline FEM $T=450 \mathrm{Nm}$ & $\mathbf{7 1}$ & $\mathbf{5 5 2}$ & - \\
\hline
\end{tabular}




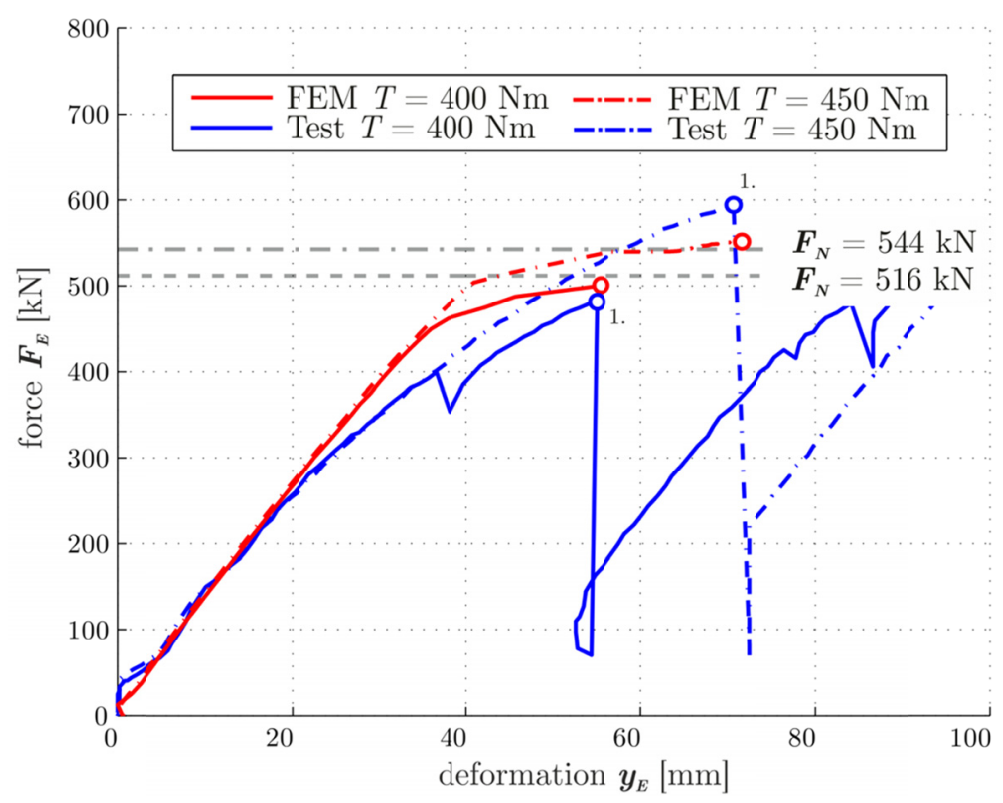

Fig. 11. Comparison of testing of yielding supports and FEM simulations

The total deformation field of the yielding support $(T=450 \mathrm{Nm})$ before the state of rigid body motion is shown in Fig. 12. The figure shows that the slipping occurs in the upper clamping joint. It is interesting that tightening the bolt (with tightening torque $T=450 \mathrm{Nm}$ ) before slipping causes large plastic deformations in similar locations to those observed in the case of the rigid support.

\section{Results and discussion}

The results of the rigid support computer model exhibit excellent agreement with the experimental testing in the laboratory at GIG Katowice (Fig. 7). This was achieved by careful modelling of not only the steel arch support, but also the pinch rolls and the test frame. If no account is taken of the stiffness of the hydraulic cylinders, the response of the support will be very different. It is therefore necessary to use boundary conditions, which are illustrated in Fig. 5. The comparison of the computer model results with experimental results of measurements in the laboratory is shown in Table 5 .

The dependence of the load on the deformation of yielding support from the beginning to the moment of the first slip was investigated in the computer model (Fig. 11). Comparison of the results of the FE model with the results of laboratory measurements is given in Tab. 6 .

For a more detailed solution response, creating the full saw tooth response character of Fig. 3 and Fig. 4, it would be necessary to describe the kinematic behaviour of friction (depending on the relative velocity between the contact surfaces) and to solve the problem as a dynamic task with the influence of inertial forces. Even without observing these effects, however, we achieved 


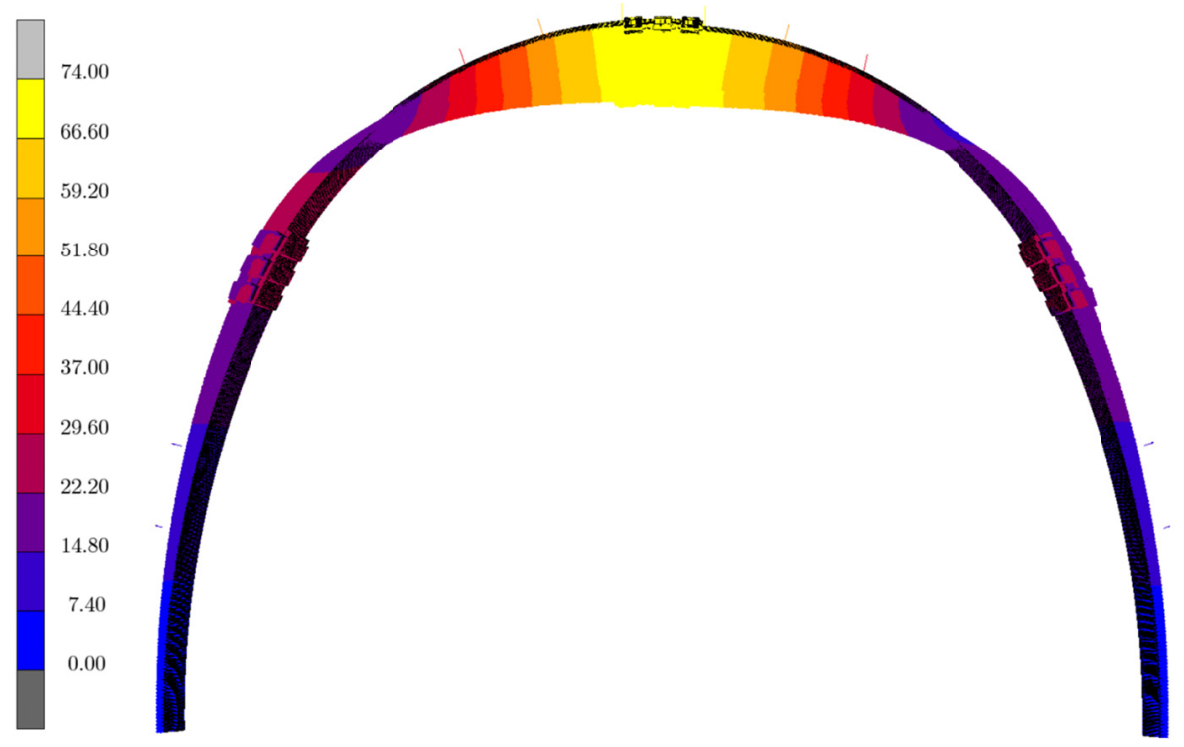

Fig. 12. Field of total deformation $\quad x \quad[\mathrm{~mm}]$ on yielding support (tightening torque of screws $T=450 \mathrm{Nm}$ ) before state of rigid body motion - load $F_{E}=552 \mathrm{kN}$

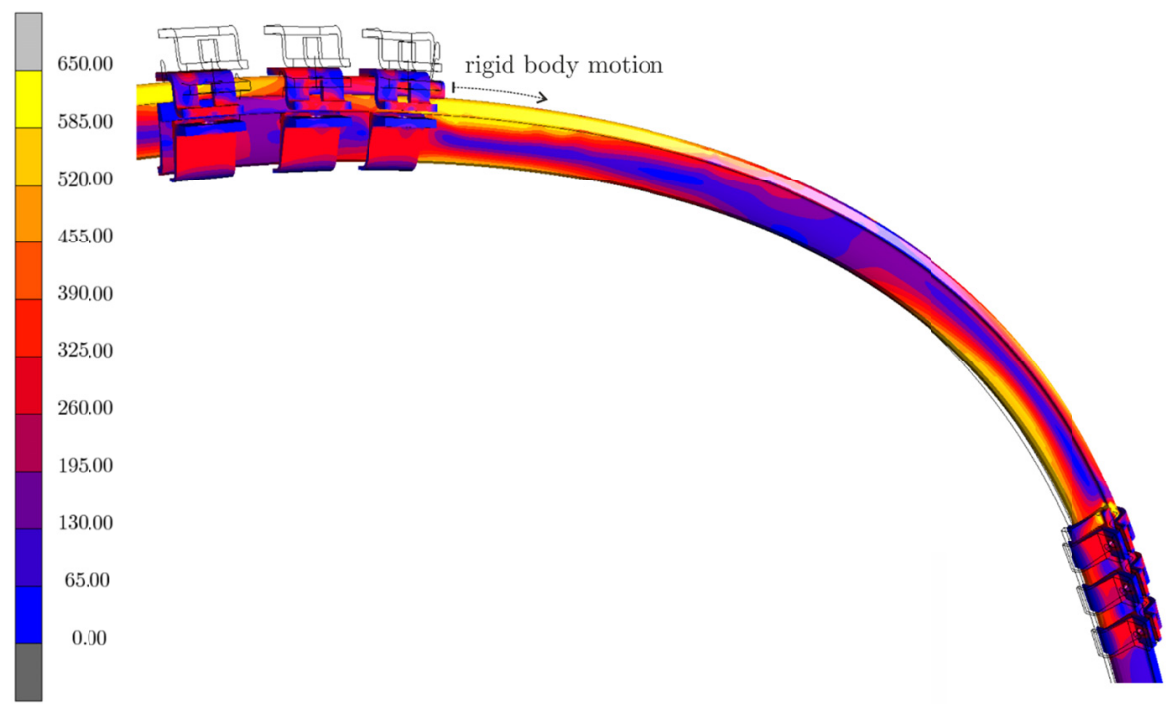

Fig. 13. Field of equivalent stress - von Mises $\sigma[\mathrm{MPa}]$ on yielding support (tightening torque of screws $T=450 \mathrm{Nm}$ ) before state of rigid body motion $-\operatorname{load} F_{E}=552 \mathrm{kN}$

satisfactory results in terms of the total load-bearing capacity of the support. On the basis of a broader set of tests of arch supports of various types and sizes (Pacześniowski \& Taborek, 2014), it was found that the loading at the moment of the first slip $F_{1}$ is very close to the total 
load-bearing capacity support $F_{N}$ under that standard (Pacześniowski \& Taborek, 2014) and corresponds to findings from practice (Majcherczyk et al., 2014).

The friction coefficients in the tuned FE model correspond with values for a slightly corroded surface (Horyl \& Šňupárek \& Maršálek, 2014).

The results show that the chosen modelling procedure reflects the considerable influence of the tightening of the friction joints on the load-bearing capacity of the yielding support.

\section{Conclusions}

The tuned computer model of the rigid steel arch support, also including a test frame with load rollers, captures very well the strength and deformation behaviour of the arch support in the unyielding version.

The computer model of the yielding support also plausibly characterizes the behaviour of the support up to the time of the first slip in the clamped joints, consistent with experiments. The value of the loading capacity of the yielding arch supports at the moment of first slip represents with sufficient accuracy the total load-bearing capacity of arch supports at the specified loading conditions.

The mathematical model reflects the influence of the tightening torque bolts of yielding friction connections on the first regular slip and load-bearing capacity of the support.

The procedure used for mathematical modelling with the results of representative laboratory tests facilitates reliable parametric studies of the behaviour of steel arch supports from the viewpoint of construction, shape, material, optimal yielding connections and a scheme of loading.

\section{Acknowledgements}

The work was supported by VŠB - Technical University of Ostrava under grant SGS SP2015/113, IT4Innovations Centre of Excellence project, Reg. No. Z.1.05/1.1.00/02.0070 supported by the Operational Programme "Research and Development for Innovations", funded by Structural Funds of the European Union and the state budget of the Czech Republic and Institute of Clean Technologies for Mining and Utilisation of Raw Materials for Energy Use - Sustainability Program, Reg. No. L01406.

\section{References}

Brodny J., 2012. Analysis of operation of new construction of the frictional joint with the resistance wedge. Arch. Min. Sci. 57, 1, 209-227.

Horyl P., Šňupárek R., Maršálek P., 2014. Behaviour of Frictional Joints in Steel Arch Yielding Supports. Arch. Min. Sci. 59, 3, 723-734.

Horyl P., Šn̆upárek R., Hlaváčková M., 2013. Loading capacity of yielding connections used in steel arch roadway supports. Proceedings of the Seventh International Symposium on Ground Support in Mining and Underground Construction. Perth: ACG - Australian Centre for Geomechanics, 461-470.

Majcherczyk T., Niedbalski Z., Malkowski P., Bednarek L., 2014. Analysis of yielding steel arch support with rock bolts in mine roadways stability aspect. Arch. Min. Sci. 59, 3, 641-654 
Pacześniowski K., Taborek W., 2012a. Standard PN-G-15000-05:1992 - "Obudowa chodników odrzwiami podatnymi z kształtowników korytkowych - Odrzwia łukowe otwarte - Badania stanowiskowe".

Pacześniowski K., Taborek W., 2012b. Sprawozdanie z badań nr BL-2/12-66 - "Stanowiskowe badania odrzwi obudowy SP 16/4 i SP 19/5 z ksztaltownika TH29 (stal 31Mn4) oraz odrzwi SP 19/6 z ksztaltownika TH34 (stal 31Mn4) / not published/.

Poruba Z., Horyl P., 2014. Posouzeni obloukové výztuže TH29. VŠB - TU Ostrava 2014, pp. 31 (in Czech).

„Steel Qualities“, 2015. Special Sections. Arcelor Mittal Rodange \& Schifflange, Web. 24 Feb. 2015. <http://www.ares. lu/4_mining.htm>. 